\title{
Uji Stabilitas Fisik Sediaan Masker Gel dari Ekstrak Alga Merah (Poryphyra sp)
}

\author{
Aurina Megawati Numberi*, Rani Dewipratiwi, Elsye Gunawan
}

Program Studi Farmasi, Fakultas Matematika dan Ilmu Pengetahuan Alam, Universitas Cenderawasih Jayapura

*email: 1995megrin.numberi@gmail.com

(Submit 28/10/2019, Revisi 15/1/2020, Diterima 28/1/2020)

\begin{abstract}
Abstrak
Tumbuhan Alga merah ini berasal kampung Sarwandori kepulauan Yapen, Serui. Kandungan kimia dalam alga merah antara lain alkaloid, terpen, dan flavonoid yang berfungsi sebagai, anti kanker, dan anti mikroba. Sediaan masker merupakan salah satu bentuk sediaan semi solida yang mampu melekat pada permukaan tempat pemakaian dalam waktu yang cukup lama sebelum sediaan ini dicuci atau dihilangkan. Tujuan penelitian ini adalah untuk mengetahui mutu fisik sediaan masker gel ekstrak alga merah dan formula terbaik. Selanjutnya metode eksperimen dilakukan untuk mengetahui uji stabilitas fisik berupa uji organ oleptik berupa warna bau dan bentuk, uji ph, uji iritasi, uji daya lekat, uji daya sebar, uji homogenitas, uji proteksi, uji keamanan, uji waktu kering dan uji penyimpanan selama 31 hari. Analisis data menggunakan SPSS Kolmogrov-Smirnov Test, ANOVA oneway, danT-Test. Hasil yang didapat pada uji organ oleptik masker berwarna bening coklat, memiliki uji homogenitas ketiga sediaan masker tidak mengalami penggumpalan, uji daya sebar berkisaran dari 741-0,59 cm, uji daya lekat berkisar antara 0,865 detik dan 0,551 detik, uji daya proteksi dari ketiga formula masker baik, uji pH hari ke 0 bernilai5,33 dan hari ke 31 bernilai 7,12, uji waktu kering hari ke 0 bernilai 4-50 menit dan hari ke 31 bernilai 15-30 menit ,uji keamanan dari 30 relawan hanya ada 3 orang relawan yang mengalami iritasi ringan dari formula I hari ke 0 sampai hari ke 31 relawan mengalami iritasi, semua pengujian dilakukan 3 kali replikasi. Dari Ketiga formula stabil, dan F II merupakan formula terbaik .
\end{abstract}

Kata kunci : Ekstrak alga merah, Masker Gel, Stabilitas Fisik.

\section{Outline}

- Pendahuluan

- Metode

- Hasil dan Pembahasan

- Kesimpulan

- Daftar Pustaka 


\section{Pendahuluan}

Rumput laut merupakan kelompok tumbuhan yang berklorofil yang terdiri atas satu atau banyak sel dan berbentuk koloni apabila ditinjau secara biologi. Rumput laut mengandung bahan-bahan organik seperti polisakarida, hormon, vitamin, mineral, dan juga senyawa bioaktif. Beberapa rumput laut juga menghasilkan metabolit yang mempunyai aktivitas antioksidan (Pakidi, 2016).

Metabolit sekunder adalah senyawa metabolit non-esensial bagi pertumbuhan organisme. Fungsinya yaitu untuk mempertahankan diri dari kondisi lingkungan yang kurang menguntungkan (Khotimah et al., 2013). Beberapa metabolit sekunder yang diisolasi dari rumput laut memiliki aktivitas bioaktif (Venkateswarlu et al., 2007).

Makroalga menghasilkan beberapa komponen bioaktif yang masuk ke dalam kelompok lemak, asam lemak, polisakarida, dan pigmen serta metabolit sekunder seperti alkaloid, fenol, lektin dan terpen (Perez et al, 2016). Oleh karena itu, makroalga memiliki manfaat sebagai tanaman pengobatan. Banyak penelitian yang sudah dilakukan untuk menganalisis aktivitas senyawa bioaktif makroalga, diantaranya alga merah sebagai antikanker (Duraikannu et al. 2014) dan antibakteri (Omar et al, 2012), alga hijau sebagai antibakteri (Mishra et al, 2016) dan antioksidan (Basir et al, 2017), serta alga coklat sebagai antidiabetes dan antiinflamasi (Ji-Hyun et al. 2016).

Perairan laut Indonesia memiliki beberapa jenis tumbuhan laut, salah satunya didominasi oleh tumbuhan alga merah (Rhodophyceae) sebanyak 452 jenis. Selain itu, terdapat sekitar 196 jenis alga hijau (Chlorophyceae) dan sekitar 134 jenis alga coklat (Phaeophyceae) yang tumbuh serta menempati perairan laut di Indonesia (Pakidi, 2016).

Masker wajah peel off merupakan salah satu jenis masker wajah yang mempunyai keunggulan dalam penggunaan yaitu dapat dengan mudah dilepas atau diangkat seperti membrane elastis (Rahmawanty et al. 2015).

Masker wajah peel off mampu meningkatkan hidrasi pada kulit, memperbaiki serta merawat kulit wajah dari masalah keriput, penuaan, jerawat dan dapat juga digunakan untuk mengecilkan pori, membersihkan serta melembabkan kulit serta bermanfaat dalam merelaksasi otot-otot wajah, sebagai pembersih, penyegar, pelembab dan pelembut bagi kulit wajah (Vieira et al. 2009; Velasco 2014; Grace et al. 2015).

Rumput laut dapat diolah terlebih dahulu menjadi bubur sebelum dipergunakan sebagai bahan baku pembutan kosmetik. Bubur rumput laut banyak dieksplorasi dalam dunia farmasi, industri dan kosmetik di antaranya yaitu perbandingan bubur rumput laut merah dan cokelat untuk pembuatan kosmetik (Luthfiyana et al. 201; Maharani et al. 2017; Yanuarti et al. 2017; Dolorosa et al. 2017; dan Nurjanah et al. 2017). 


\section{Metode}

Metode penelitian ini dilakukan secara eksperimen merupakan metode percobaan yang sistematis dalam suatu situasi khusus, dimana gejala-gejala yang diamati begitu disederhanakan,yaitu hanya beberapa faktor saja yang diamati,sehingga peneliti dapat mengatasi seluruh proses eksperimennya. Kegiatan penelitian bertujuan untuk mengetahui hasil yang diperoleh pada penelitian Uji Stabilitas Fisik Sediaan Masker Dari Ekstrak Alga Merah (Poryphyra sp). Penelitian ini akan dilaksanakan selama 3 bulan dimulai pada bulan juni sampai bulan agustus 2019 dan berlokasi di Laboratorium Farmasi Jurusan Farmasi Fakultas Matematika dan IImu Pengetahuan Alam Universitas Cenderawasih Jayapura.Pembuaatan sediaan Masker gel, evaluasi mutu fisik sediaan seperti homogenitas sediaan,pengamatan stabilitas sediaan meliputi perubahan warna,bau,pengukuran $\mathrm{pH}$, pengujian waktu sediaan mengering, uji daya sebar, uji daya lekat, uji iritasi, terhadap perawatan kulit

\section{Populasi dan Pengambilan Sampel}

Populasi yang dimaksud adalah alga merah yang terdapat di Perairan Kabupaten Kepulauan Yapen Serui dikampung (Sarwandori) Pengambilan sampel dilakukan di perairan kabupaten Yapen Serui di kampung (Sarwandori). Sampel adalah Poryphyra sp yang di buat simplisia sebanyak 100 gram.

\section{Alat dan Bahan}

Alat-alat yang digunakan dalam penelitian ini yaitu gelas ukur,gelas beaker, alumunium foil,corong, cawan porselin, objek gelas, oven,,penggiling rumput laut,, ayakan mesh, neraca analitik, penangkas air, hot plate, mortar dan stampel, pipet tetes, batang pengaduk,tabung reaksi, $\mathrm{pH}$ meter, wadah masker dan alat-alat lain yang dapat digunakan dalam laboratium farmasi

Bahan-bahan yang digunakan dalam penelitian ini antara lain:Alga merah ,asal Kabupaten Kepulauan Yapen Serui kampung Sarwandori,pelarut etanol 70\%, bahan untuk membuat masker aquades, polivinil alkohol, propilen glikol,Metil paraben,Propil paraben, Carbopol dan alga merah.

\section{Pengumpulan sampel}

Bahan alga merah (Poryphyra sp) . yang akan digunakan pada penelitian diperoleh dari Perairan kabupaten Kepulauan Yapen Serui khususnya Kampung Sarwandori.

\section{Pembuatan simplisia}

Alga merah (Poryphyra sp). yang diperoleh dari Perairan kabupaten Kepulauan Yapen Serui khusus dikampung Sarwandori diangkat dari laut (kedalaman Budi daya rumput laut di bagi menjadi 2 sebagai berikut:.1. Kedalaman 1-3 meter dan 2. Kedalaman 30$40 \mathrm{~cm}$ di dasar laut yang ke dalamnya $\pm 1-3 \mathrm{~m}$ waktu air pasang) menggunakan tangan dicuci dengan air laut untuk menghilangkan pasir-pasir dan kotoran yang menempel. Lalu dimasukkan kedalam kantong plastik selama pengangkutan. 
Setelah itu sampel dibersihkan dengan menggunakan air bersih untuk membersihkan kotoran-kotoran yang masih menempel. Sampel direndam selama satu hari dengan tujuan untuk menghilangkan garamnya. Selanjutnya sampel ditiriskan, ditimbang dan dikeringkan dengan diletakkan di tempat yang tidak terkena sinar matahari langsung sampai kering. Sampel yang sudah dikeringkan kemudian dihancurkan dengan menggunakan pengiling rumput laut menjadi serbuk halus dan diayak dengan ukuran ayakan no.60 mesh.

\section{Pembuatan Ekstrak Alga Merah (Poryphyra sp)}

Sebanyak $100 \mathrm{~g}$ serbuk simplisia .Proses ekstraksi dilakukan dengan metode maserasi menggunakan etanol 70\% 1,5 L dengan perbandingan (1:15) selama tiga hari, dengan pengadukan 30 menit setiap harinya. Setelah tiga hari dilakukan penyaringan, kemudian filtrat diuapkan pelarutnya dengan alat rotary evaporator sehingga didapatkan ekstrak pekat. Ekstrak yang diperoleh kemudian ditimbang, dicatat kemudian dihitung \% rendemennya (Dikjen Pom, 2000). Formulasi pembuatan masker diambil berdasarkan penelitian tentang ekstrak alga merah yang digunakan.

\section{Formulasi Sediaan Ekstrak Masker Gel}

Bahan-bahan fase minyak (propil paraben) dan fase air (ekstrak alga merah ,carbopol, metil paraben,propilen glikol dan aquadest) dipisahkan. Fase minyak dan fase air dipanaskan hingga suhu $70-80^{\circ} \mathrm{C}$. Setelah semuanya melebur, fase air dimasukkan sedikit demi sedikit ke dalam fase minyak dan diaduk perlahan-lahan hingga terbentuk basis masker ( Risha, 2016).

Tabel 1. Formula Masker Gel

\begin{tabular}{|l|c|c|c|}
\hline \multicolumn{1}{|c|}{ Nama Bahan } & \multicolumn{3}{|c|}{ Formula (gram) } \\
\cline { 2 - 4 } & 1 & 2 & 3 \\
\hline Ekstrak Alga Merah & 0,5 & 0,5 & 0,5 \\
\hline Polivinil alkohol & 12 & 14 & 16 \\
\hline Propilen Glikol & 10 & 10 & 10 \\
\hline Propil Paraben & 0,02 & 0,02 & 0,02 \\
\hline Metil Paraben & 0,05 & 0,05 & 0,05 \\
\hline Etanol 70\% & 4 & 4 & 4 \\
\hline Carbopol & 0,15 & 0,15 & 0,15 \\
\hline Aquades & 33,28 & 31,28 & 29,28 \\
\hline Total & $60 \mathrm{ml}$ & $60 \mathrm{ml}$ & $60 \mathrm{ml}$ \\
\hline
\end{tabular}




\section{Formulasi Masker Gel}

Cara Pembuatan Masker

Bagian II ( Polivinil alkohol, aquades) dileburkan di atas penangas air sambil diaduk. Bagian II yang sudah lebur dimasukkan ke dalam mortar hangat.

Bagian III ( Propil glikol) di campurkan sedikit-demi sedikit ke dalam Bagian II sambil di gerus dengan kecepatan konstan.

Bagian IV ( Metil paraben, Propil paraben) Hangatkan cawan proselin lalau di campurkan jadi satu dan di aduk sampai tercampur kemudian masukkan dalam Bagian II sambil di gerus.

Bagian I ( Ekstrak alga merah di campurkan dengan Etanol 70\%) sambil tercampur dan masukkan dalam Bagian II sambil terus di gerus hingga mencapai suhu kamar.

Bagian V ( Carbopol) di taburkan sedikit-demi sedikit ke dalam Bagian II sambil di gerus sampai mengental.

Masker dimasukkan ke dalam wadah dan di tutup rapat.

\section{Uji Organoleptik}

Pengamatan organoleptis dapat dinilai dengan pengamatan dari segi tekstur, bau,bentuk, dan warna sediaan.Waktu lepas dari kulit 10:15 menit. Pengukuran dilakukan setiap minggu selama 4 minggu penyimpanan pada suhu $26 \pm 2^{\circ} \mathrm{C}$ dan suhu $40^{\circ} \mathrm{C}$ (Risha, 2016).

\section{Uji $p H$}

Sediaan masker ekstrak Alga Merah sebanyak 1gram diencerkan dengan $10 \mathrm{~mL}$ aquadest. Pengukuran $\mathrm{pH}$ masker dilakukan menggunakan $\mathrm{pH}$ meter. Sebelum digunakan $\mathrm{pH}$ meter dikalibrasi terlebih dahulu dengan larutan buffer standar $(\mathrm{pH} \mathrm{4,5}$ dan $\mathrm{pH}$ 6,5). Sediaan masker ditempatkan dalam wadah, kemudian diukur $\mathrm{pH}$ nya. Pengukuran dilakukan setiap minggu selama 4 minggu penyimpanan pada suhu $26 \pm$ $2^{\circ} \mathrm{C}$ dan suhu $40^{\circ} \mathrm{C}$ Nilai $\mathrm{pH}$, sehingga mendapat sediaan yang aman untuk kulit, kemudian didapat nilai pH (Risha, 2016).

\section{Uji Homogenitas}

Uji homogenitas sediaan dilakukan dengan cara mengamati hasil pengolesan masker pada plat kaca. Masker yang homogen ditandai dengan tidak terdapatnya gumpalan pada hasil pengolesan, struktur yang rata dan memiliki warna yang seragam dari titik awal pengolesan sampai titik akhir pengolesan.

\section{Uji Daya sebar}

Ditimbang 1 gram masker, kemudian diletakan diantara lempeng kaca berdiameter 15 $\mathrm{cm}$. Lempeng kaca bagian atas ditimbang terlebih dahulu kemudian diletakan diatas masker dan dibiarkan 5 menit. Diatasnya diberi 50 gram beban tambahan, dibiarkan 5 menit dan diukur diameter sebarnya. 
Kemudian ditambah kembali beban dengan berat 100 gram bebean tambahan,dibiarkan 5 menit dan diukur diameternya sebarnya.Kemudian tambahkan kembali beban dengan maksimum 150 gram dan diukur kembali diameter sebarnya (Swastika et al, 2013).

\section{Uji Daya lekat}

Maker diambil sebanyak $0,25 \mathrm{~g}$ diletakkan pada gelas obyek dan ditekan dengan beban $500 \mathrm{~kg}$ selama 5 menit. Setelah gelas obyek dipasang pada alat tes, diberi beban $80 \mathrm{~g}$ dan kemudian dicatat waktu pelepasan masker dari gelas obyek.

\section{Uji Proteksi}

Siapkan kertas saring $(10 \times 10 \mathrm{~cm})$ dibasahi dengan fenolftalein dan dikeringkan. Masker ditimbangkan sebanyak 1gram, kemudian dioleskan dengan masker diataskertas tersebut. Pada kertas saring yang lain dibuat suatu area $(2,5 \times 2,5 \mathrm{~cm})$ pada pinggirnya dibatasi dengan parafin cair. Kertas saring ditempelkan diatas kertas saring sebelumnya. Larutan $\mathrm{KOH} 0,1 \mathrm{~N}$ diteteskan pada area tersebut, kemudian diamati ada tidaknya noda merah pada waktu $15,30,45,60$ detik, 3 dan 5 menit, jika tidak ada noda berarti masker memberikan proteksi. (Fadeelah, 2015).

\section{Uji Stabilitas}

Formula yang telah dibuat kemudian dituang ke dalam wadah sebanyak $10 \mathrm{ml}$, disimpan selam 31 hari. Masker ini kemudian dilakukan evaluasi meliputi uji organoleptik, uji pH, uji homogenitas, uji daya sebar, dan uji daya lekat. (Desti. I, 2014).

\section{Uji Keamanaan}

Pengujian keamanan sediaan masker yang telah dibuat dan dilakukan terhadap 30 sukarelawan dengan uji temple terbuka, serta dengan mengisi kuisioner. Sejumlah sediaan uji dioleskan pada tangan sukarelawan dan dibiarkan terbuka selama 15 menit. Jika tidak ada reaksi diberi tanda (-), jika kulit merasa iritasi/gatal diberi tanda (++), jika kemerahaan diberi tanda (+++). (Yuniarsih, 2010).

\section{Uji Kuisioner Kesukaan}

Uji kesukaan sediaan masker ekstrak alga coklat dilakukan dengan menggunakan metode kuisioner yang terdiri dari data personal dan data produk. Data personal meliputi nama dan paraf responden, sedangkan data produk dengan melakukan evaluasi sensorik terhadap masker meliputi tekstur, warna, dan bau. Uji Kesukaan dilakukan dengan menggunakan 30 responden (Saprilanti, 2015).

\section{Uji Waktu kering}

Sampel masker gel peel-off sebanyak $1 \mathrm{~g}$ dioleskan pada kulit punggung tangan. Kecepatan mongering masker gel pee-off ditandai hingga membentuk lapisan film dari masker untuk dapat mongering dapat dilihat menggunakan stopwatch, uji waktu sediaan mongering mengacu pada metode ( Shai et al, 2009). 


\section{Hasil dan Pembahasan}

\section{Preparasi sampel}

Penelitian ini menggunakan Alga merah (Poryphyra $\mathrm{sp}$ ) atau di kalangan masyarakat di sebut dengan rumput laut yang diperoleh dari Kampung Sarwandori, Kabupaten Kepulauan Yapen. Alga merah dihaluskan menjadi serbuk simplisia yang dilakukan dengan cara mengiris kecil-kecil Alga merah tersebut kemudian diangin-anginkan, di jemur di bawah panas matahari dan mennggunakan penggiling rumput laut hingga menjadi serbuk. Proses pengecilan ukuran partikel ini dilakukan untuk memperluas bidang permukaan bahan sehingga akan mempercepat penetrasi pelarut ke dalam bahan yang akan diekstrak dan mempercepat waktu ekstraksi.

Tabel 2. Hasil pembuatan ekstrak

\begin{tabular}{|c|c|c|}
\hline $\begin{array}{c}\text { Berat simplisia } \\
\text { awal (gram) }\end{array}$ & Berat ekstrak (gram) & Rendemen \% \\
\hline 100 & 0,027 & 0,027 \\
\hline
\end{tabular}

Berdasarkan hasil pembuatan ekstrak dengan metode maserasi dari (Tabel 4.1) didapat perhitungan $\%$ rendemen ekstrak alga merah $0,027 \%$.

Simplisia alga merah sebanyak 100 gram direndam 3 kali 24 jam dengan menggunakan etanol $70 \%$ sebanyak $1 \mathrm{~L}$ dan dilakukan pengadukan setiap 1 kali 24 jam, kemudian dilakukan penyaringan dengan bantuan kertas saring. Filtrat yang didapat diperoleh kemudian diuapkan pelarutnya menggunakan rotary vacum evaporator pada suhu $50^{\circ} \mathrm{C}$ sampai diperoleh ekstrak kental.

Hasil uji organoleptik sediaan masker gel alga merah (Poryphyra sp)

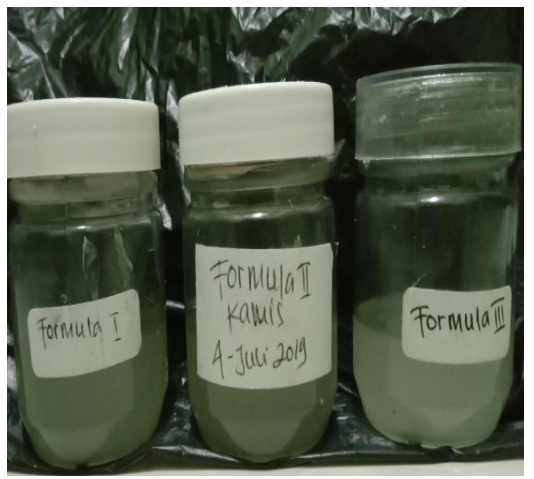

Gambar 2. Hasil uji ogranoleptik

Pengujian terhadap sediaan masker gel secara organoleptik merupakan salah satu langkah penentuan kualitas suatu sediaan masker gel yang dihasilkan. Berikut adalah Tabel pengujian masker gel alga merah. 
Tabel 3. Uji organoleptik sediaan masker gel alga merah (Poryphyra sp)

\begin{tabular}{|c|c|c|}
\hline \multirow[t]{2}{*}{ Formula } & \multicolumn{2}{|c|}{ Uji organoleptik } \\
\hline & Hari ke 0 & Hari ke 31 \\
\hline \multirow[t]{4}{*}{ I } & Lembut & Lemut \\
\hline & Bening keabuan & Bening \\
\hline & Khas basis & Khas Basis \\
\hline & Semi solid & Semi solid \\
\hline \multirow[t]{4}{*}{ II } & Lembut & Lembut \\
\hline & Bening coklatan & $\begin{array}{c}\text { Bening sedikit } \\
\text { coklat }\end{array}$ \\
\hline & Khas basis & Khas basis \\
\hline & Semi solid & Semi solid \\
\hline \multirow[t]{4}{*}{ III } & Lembut & Lembut \\
\hline & Bening coklat & Keruh \\
\hline & Khas basis & Ekstrak \\
\hline & Semi solid & Semi solid \\
\hline
\end{tabular}

Hasil uji organoleptik menunjukkan warna yang dihasilkan hampir tidak dapat dibedakan antara F I, F II, dan F III, hal ini dipengaruhi oleh konsentrasi ekstrak yang digunakan yaitu $0,5 \mathrm{~g}$ untuk tiap formula, bau masker gel didominasi oleh bau basis, hal ini disebabkan pada komposisi sediaan masker gel tidak menggunakan bahan pewangi/parfum. Sediaan masker gel alga merah FI, FII dan FIII memiliki tekstur yang lembut, hal ini berkaitan dengan ketercampuran dari komponen bahan pembentuk masker gel yang cukup baik, sedangkan bentuk sediaan masker gel berbentuk semi padat. Pada pengujian stabilitas hari ke 31 secara organoleptik tidak terjadi perubahan warna, bau, tekstur dan bentuk, yang artinya secara organoleptik masker gel masih dalam keadaan stabil mulai dari hari ke 0 hingga hari ke 31 .

Uji Homogenitas Mikroskopik Dan Makroskopik Sediaan Masker Gel Ekstrak Alga Merah (Poryphyra sp).

Homogenitas dari suatu sediaan semisolid dapat mempengaruhi pengaplikasikan sediaan pada kulit.

Tabel 4. Uji homogenitas sediaan masker gel alga merah (Poryphyra sp)

\begin{tabular}{|c|c|c|}
\hline \multirow{2}{*}{ Formula } & \multicolumn{3}{|c|}{ Uit homogenitas } \\
\hline I & Hari ke 0 & Hari ke 31 \\
\hline II & + & + \\
\hline III & + & + \\
\hline
\end{tabular}


Sediaan masker gel tidak boleh terdapat gumpalan-gumpalan partikel di dalamnya baik secara mikroskopik dan makroskopik (Safitri dkk,2014). Hasil pada tabel 4.3 menunjukkan bawah ke tiga formula merupakan maser gel yang merata dan tidak terdapat butiran-butiran dari F I, F II, dan F III homogen karena tidak terdapat butiranbutiran kasar, dan dioleskan pada lempeng kaca untuk pengujian secara makroskopik baik hari ke 0 ketiga Formula homogen, sampai hari ke 31 Sedangkan secara mikroskopik dari ketiga formula juga menunjukan sediaan masker gel homogen, hal ini ditunjukkan dengan penyebaran butir-butir pertikel minyak yang terdispersi secara merata di dalam partikel air dan tidak membentuk gerombol atau gumpalan partikel yang tidak homogen.

\section{Hasil Uji Daya Sebar Sediaan Masker Gel Ekstrak Alga Merah (Poryphyra sp)}

Daya sebar merupakan kemampuan penyebaran sediaan ketika digunakan pada kulit, semakin besar daya sebar maka semakin luas pula zat aktif akan terdistribusi dengan baik.

Tabel 5. Nilai rata-rata uji daya sebar sediaan masker gel alga merah

(Poryphyra sp)

\begin{tabular}{|c|c|c|c|c|c|c|}
\hline \multirow{3}{*}{$\begin{array}{l}\text { Beban } \\
\text { (Gram) }\end{array}$} & \multicolumn{6}{|c|}{ Rata-Rata Daya Sebar (Cm) } \\
\hline & \multicolumn{3}{|c|}{ Formula Hari Ke 0} & \multicolumn{3}{|c|}{ Formula Hari Ke 31} \\
\hline & 1 & II & III & I & II & III \\
\hline 0 & 6 & 6 & 7 & 7.2 & 6 & 6 \\
\hline 50 & 6.7 & 7 & 7 & 7.3 & 7 & 7.3 \\
\hline 100 & 7 & 7 & 7 & 7.6 & 7.5 & 7.5 \\
\hline 150 & 7.1 & 7 & 7 & 7 & 7 & 7 \\
\hline
\end{tabular}

Hasil uji daya sebar dilakukan untuk melihat kemampuan menyebarnya gel diatas permukaan kulit saat pemakaian sediaan. Gel yang baik membutuhkan waktu yang lebih sedikit untuk tersebar dan memiliki nilai daya sebar yang tinggi (Garg et al, 2002:89). Uji daya sebar hari ke 0 mununjukkan FI memiliki daya sebar lebih kecil dari pada FII dan FIII (menurut Aryani 2015), Viskositas suatu sediaan sangat berpengaruh pada luas penyebarannya, semakin rendah viskositas suatu sediaan maka daya sebar akan semakin besar, sehingga hal ini diduga dipengaruhi oleh viskositas dari masingmasing formula dimana pada komponen masker gel dibuat konsentrasi air menurun dari F I dan FII memiliki konsentrasi air lebih rendah dibanding Formula III lebih luas sehingga penyebarannya lebih luas dibandingkan FI, F II dan F III. Pengujian mutu fisik daya sebar secara statistik dengan ANOVA oneway menunjukan nilai signifikan 0.741 $>0.05$ nilai rata-rata daya sebar ketiga sediaan gel alga merah tidak berbeda secara nyata Lampiran halaman 48.

Sedangkan pada hari ke 31 terjadi peningkatan daya sebar yang diduga dipengaruhi oleh penurunan viskositas sediaan akibat oksidasi komponen masker gel oleh faktor suhu. 
Menurut Suardi dkk, daya menyebar tidak bisa dijadikan sebagai data absolut karena tidak ada literature yang menyebutkan angka idealnya secara pasti,sementara (menurut Dini 2015), daya sebar masker gel dikatakan baik apabila penyebaran masker gel semakin meningkatkan seiring dengan meningkatnya beban yang diberikan, sehingga ke tiga formula pada penelitian ini dapat dikatakan masih memenuhi syarat daya sebar sediaan semi solid, hal ini ditunjukkan dengan meningkatnya penyebaran sediaan masker gel seiring dengan peningkatan beban yang diberikan.

Pengujian stabilitas daya sebar masker gel alga merah dengan $T$-Test menunjukan nilai signifikan FI 0,044 (>0,05); FII 0,450 (>0,05); FIII 0,019 (>0,05), maka daya sebar sediaan gel alga merah ketiga FI, FII, dan FIII dari hari ke 0 sampai hari ke 31 dapat diterima, yang artinya daya sebar dari ketiga formula secara stabil.Berdasarkan uji daya lekat,uji daya sebar ,uji homogenitas ,uji pH dari ketiga Formula tidak berbeda jauh sedangkan pHnya di hari ke 0 baik sedangkan hari ke 31 terjadi perubahan nilai $\mathrm{pH}$ akan terpengaruh oleh media yang terdekomposisi oleh suhu tinggi saat penyimpanan yang menghasilkan asam atau basa ini yang mempengaruhi $\mathrm{pH}$.

\section{Hasil uji daya lekat sediaan masker gel ekstrak alga merah (Poryphyra sp)}

Daya lekat akan menjamin waktu kontak yang efektif dengan kulit sehingga tujuan penggunaannya tercapai

Tabel 6. Nilai rata-rata uji daya lekat

\begin{tabular}{|l|l|l|}
\hline \multirow{2}{*}{ Formula } & \multicolumn{2}{|l}{ Uji daya lekat (detik) } \\
\cline { 2 - 3 } & Hari ke 0 & Hari ke 31 \\
\hline I & 0.23 Menit & 0.15 Menit \\
\hline II & 0.28 Menit & 0.18 Menit \\
\hline III & 0.52 Menit & 0.19 Menit \\
\hline
\end{tabular}

Hasil uji daya lekat hari ke 0 menunjukkan bahwa daya lekat ke tiga formula berbanding terbalik dengan daya sebar yaitu FI dan FII memiliki daya lekat yang lebih singkat di bandingkan FIII, hal ini dipengaruhi oleh jumlah basis yang dibuat meningkatkan dari FI dan FIl sehingga viskositas lebih rendah waktu lekat FIII lebih lama. Pengujian mutu fisik daya lekat secara statistik dengan ANOVA oneway menunjukan nilai signifikan $0.865>0.05$ nilai rata-rata daya lekat ketiga sediaan gel alga merah tidak berbeda secara nyata.

Sedangkan pada uji stabilitas penyimpanan 31 hari, masing-masing formula memiliki daya lekat yang cnederung semakin menurun waktu daya lekatnya, menurut Nurlaela dkk 2012, daya lekat sediaan masker gel yang menurun akibat oksidasi komponen masker gel sehingga terjadi penurunan daya lekat, namun daya lekat ke tiga formula masih memenuhi syarat daya lekat sediaan topikal yang baik yaitu tidak kurang dari 4 detik (Susanti dan kusmiyarsih, 2011). 
Pengujian stabilitas daya lekat masker gel alga merah dengan T-Test menunjukan nilai signifikan FI 0,107 (>0,05); FII 0,237 (>0,05); FIII 0,852 (>0,05), maka daya lekat sediaan gel alga merah (Poryphyra sp) ketiga FI, FII, dan FIII dari hari ke 0 sampai hari ke 31 dapat diterima, yang artinya daya lekat dari ketiga formula secara stabil. .Berdasarkan uji daya lekat,uji daya sebar ,uji homogenitas ,uji pH dari ketiga Formula tidak berbeda jauh sedangkan pHnya di hari ke 0 baik sedangkan hari ke 31 terjadi perubahan nilai pH akan terpengaruh oleh media yang terdekomposisi oleh suhu tinggi saat penyimpanan yang menghasilkan asam atau basa ini yang mempengaruhi $\mathrm{pH}$.

Hasil uji daya proteksi sediaan masker gel ekstrak alga merah (Poryphyra sp)

Uji daya proteksi bertujuan untuk mengetahui kemampuan masker gel melindungi kulit dari pengaruh luas seperti sinar matahari dan polusi ( Zam-zam, dkk, 2014).

Tabel 7. Uji daya proteksi sediaan masker gel alga merah (Poryphyra $s p$ )

\begin{tabular}{|c|r|r|r|r|r|r|}
\hline \multirow{2}{*}{ Formula } & \multicolumn{7}{|c|}{ Waktu proteksi hari ke 0 } \\
& 15 detik & 30 detik & 45 detik & 60 detik & 3 menit & 5 menit \\
\hline I & - & - & + & + & + & + \\
\hline II & - & - & + & + & + & + \\
\hline III & - & - & + & + & + & + \\
\hline
\end{tabular}

\begin{tabular}{|r|r|r|r|r|r|r|}
\hline \multirow{2}{*}{ Formula } & \multicolumn{7}{|c|}{ Waktu proteksi hari ke 31} \\
& 15 detik & 30 detik & 45 detik & 60 detik & 3 menit & 5 menit \\
\hline I & - & + & + & + & + & + \\
\hline II & - & - & - & + & + & + \\
\hline III & - & + & + & + & + & + \\
\hline
\end{tabular}

Keterangan : Terbentuk noda, (+), Tidak terbentuk noda (-)

Berdasarkan hasil uji daya proteksi dari ketiga formulasi masker gel baik hari ke 0 maupun hari ke 31 yang dilakukan, semua formula mampu memberikan proteksi terhadap kulit. Hal ini ditunjukkan dengan adanya noda merah yang terbentuk pada kertas saring saat ditetesi menggunakan $\mathrm{KOH} \mathrm{0,1} \mathrm{N.} \mathrm{Lampiran} \mathrm{halaman} 50$.

\section{Hasil uji pH sediaan masker gel alga merah (Poryphyra sp)}

Pengujian $\mathrm{pH}$ dimaksudkan untuk dapat mengetahui beberapa nilai keasaman dari suatu sediaan topical yang di buat.

Hasil pengujian pH menunjukkan bahwa sediaan masker gel F I, F II dan FIII pada hari ke 0 berada pada rentang pH 5 yang berarti bahwa sediaan masker gel ekstrak alga merah stabil dan hari ke 31 berada pada rentang 7,12, karena pH kulit tersebut berada pada rentang 4,5-6,5. 
Tabel 8. Uji pH sediaan masker gel alga merah (Poryphyra $\mathrm{sp}$ )

\begin{tabular}{|c|c|c|}
\hline \multirow{2}{*}{ Formula } & \multicolumn{2}{|c|}{ Uit pH } \\
\hline I & Hari ke 0 & Hari ke 31 \\
\hline II & 5 & 7.12 \\
\hline III & 5 & 7.08 \\
\hline
\end{tabular}

Perubahan $\mathrm{pH}$ sediaan selama penyimpanan menandakan kurang stabilnya sediaan selama penyimpanan. Ketidak stabilan ini dapat merusak produk selama penyimpanan atau penggunaan. Perubahan nilai $\mathrm{pH}$ akan terpengaruhi oleh media yang terdekomposisi olleh suhu tinggi saat pembuatan atau penyimpanaan yang menghasilkan asam atau basa. Asama tau basa ini mempengaruhi $\mathrm{pH}$. Selain itu perubahan $\mathrm{pH}$ juga disebabkan faktor lingkungan seperti suhu, penyimpanaan yang kurang baik, kombinasi ke tiga ekstrak yang kurang stabil dalam sediaan karena teroksidasi ( Young et al .,2002). Lampiran halaman 49.

\section{Hasil uji iritasi sediaan masker gel ekstrak alga merah (Poryphyra sp)}

Pengujian iritasi dimaksudkan untuk mengetahui keamanaan dari sediaan masker gel yang di buat.

Tabel 9. Uji iritasi sediaan masker gel ekstrak alga merah (Poryphyra sp)

\begin{tabular}{|c|c|c|c|}
\hline \multirow{2}{*}{ Formula } & \multicolumn{3}{|c|}{ Ui Iritasi hari Ke 0 } \\
\cline { 2 - 4 } & Iritasi & Tidak Iritasi & Total Panelis \\
\hline I & 2 & 28 & 30 \\
\hline II & Tidak iritasi & 30 & 30 \\
\hline III & Tidak iritasi & 30 & 30 \\
\hline & & & \\
\hline Formula & & Uji iritasi ke 31 & \\
\hline & Iritasi & Tidak Iritasi & Total Panelis \\
\hline I & 1 & 29 & 30 \\
\hline II & Tidak iritasi & 30 & 30 \\
\hline III & Tidak iritasi & 30 & 30 \\
\hline
\end{tabular}

Hasil pengujian iritasi pada hari ke 0 menunjukkan bahwa dari 30 orang panelis terdapat 2 orang relawan yang mengalami iritasi terhadap penggunaan Formula I terdapat 2 relawan yang mengalami iritasi ringan berupa panas, gatal dan kemerahan pada kulit, tetapi dalam waktu beberapa menit iritasi akan hilang sendangkan pada formula II, tidak mengalami iritasi dalam bentuk rasa panas,kemerahan dan gatal-gatal pada kulit panelis, sedangkan formula III, tidak mengalami kemerahan,panas dan gatal -gatal pada kulit. 
Hal ini berkaitan dengan nilai pH sediaan masker gel ekstrak alga merah (Poryphyra $s p$ ) yang memenuhi rentang $\mathrm{pH}$ kulit masing-masing panelis berbeda jenis kulit sehingga ada yang kurang aman dan aman untuk penggunaan topikal.

Setelah uji penyimpanan sampai pada hari ke 31 ditemukan 1 dari 30 panelis yang mengalami iritasi terhadap penggunaan Formula I, mengalami iritasi berupa panas dan gatal -gatal pada kulit pada Formula II dan F III tidak mengalami iritasi hal ini disebabkan karena perbedaan jenis kulit dari masing-masing panelis, namun sebagian besar panelis mengaku aman dalam menggunakkan sediaan masker gel ekstrak alga merah (Poryphyra sp) masih aman untuk digunakan.Lampiran Halaman 50.

\section{Hasil Uji waktu kering}

Pengujian waktu sediaan mengering dimaksudkan untuk mengetahui berapa lama waktu kering di tangan panelis.

Tabel 10. Uji waktu kering masker gel alga merah (Poryphyra sp)

\begin{tabular}{|c|c|c|}
\hline \multirow{2}{*}{ Formula } & Waktu kering hari ke 0 dan hari ke 31 (Menit) \\
\cline { 2 - 3 } & Hari ke 0 & Hari ke 31 \\
\hline I & $4-50$ menit & $20-15$ menit \\
\hline II & $19-20$ menit & $15-30$ menit \\
\hline III & $18: 50$ menit & $20: 30$ menit \\
\hline
\end{tabular}

Pengujian waktu kering gel bertujuan untuk mengetahui berapa lama gel mengering pada permukaan kulit dan membentuk lapisan film. Waktu kering dari ketiga formula masker gel alga merah berkisar antara 4-50 menit sampai 18-50 menit diformula ke 0 sedangkan pada hari ke 31 berkisar 20-15 menit sampai 20-30 menit. Dari data yang diperoleh ketiga formula masker gel alga merah yang memenuhi waktu kering masker gel alga merah yang baik sediaan F II, dan F III, yaitu antara 15-30 menit.Data pengujian waktu kering dapat dilihat pada Lampiran halama 51-52.

\section{Kesimpulan}

Berdasarkan hasil penelitian yang telah dilakukan dapat disimpulkan bahwa basis formula terbaik pada penelitian ini adalah F II dengan komposisi fase minyak lebih sedikit namun memenuhi syarat sediaan semi solid. Berdasarkan pengujian stabilitas yang telah dilakukan pada ketiga formula sediaan masker ekstrak alga merah (Poryphyra sp), bahwa formula I, II, dan III stabil meliputi uji organoleptik, uji ph, uji homogenitas, uji daya sebar, uji daya lekat, uji keamanan, dan uji proteksi dan uji waktu kering. Ketiga formula memiliki basis yang bagus, namun dari ketiga formula basis formula IIII yang lebih bagus, formula II dikatakan baik karena memenuhi semua syarat pengujiuan. Dibandingkan dengan formula I yang mengalami iritasi ringan pada hari ke 0 dan hari ke 31 dan memiliki daya sebar yang baik. 


\section{Daftar Pustaka}

Abdassah, M., T. Rusdiana, A. Subghan, dan G. Hidayati. 2009. Formulasi Gel Pengelupas Kulit Mati yang Mengandung Etil Vitamin C dalam Sistem Penghantaran Macrobead. Jurnal Ilmu Kefarmasian Indonesia. 7 (2): 105-111.

Ansel , H. C. 2005. Pengantar Bentuk Sediaan Farmasi Edisi 4. Penerjemahan: Farida Ibrahim. Jakarta: UI Press.

Anef, M. 1994. Farmasetika, Cetakan Keempat. Yogjakarta: Gadjah Mada University Press.

Aslan L M. 1998. Budidaya Rumput Laut. Yogyakarta : Kanisius.

Balboa, E.M., Conde, E., Moure, A., Falqué, E., dan Domínguez, H. 2013. In Vitro Antioxidant Properties of Crude Extracts and Compounds from Brown Algae. Food Chemistry. 138(2): 17641785

Basir A, Tarman K, Desniar. 2017. Aktivitas Antibakteri dan Antioksidan Alga Hijau Halimeda gracilis dari Kabupaten Kepulauan Seribu. Jurnal Pengolahan Hasil Perikanan Indonesia (JPHPI). $20(2)$.

Barbosa, M., Valentao, P., dan Andrade, P.B. 2014. Bioactive Compounds from Macroalgae in the New Millennium: Implications for Neurodegenerative Diseases. Marine Drugs. 12(9): 49344972.

Cowan, M.M. 1999. Plant Products as Antimicrobial Agents. Clinical Microbiology Reviews. 12(4): 564-82.

[Depkes RI] Departemen Kesehatan Republik Indonesia. 1995. Farmakope Indonesia. Edisi IV. Jakarta (ID) : Departemen Kesehatan Republik Indonesia.

Direktor Jendaral Pengawas Obat dan Makanan. (1979). Material Medikal Indonesia. Jilid III. Depertemen Kesehatan RI. Jakarta.

Ditjen POM, 2000. Parameter Standar Umum Ekstrak Tumbuhan Obat.Jakarta : Depkes RI

Duraikannu, K., Shameem, R.K., Anithajothi, R., Umagowsalya, G., Ramakritinan, C.M. 2014. Invivo Anticancer Activity of Red Algae (Gelidiela acerosa and Acanthophora spicifera). International Journal of

Dolorosa MT, Nurjanah, Purwaningsih S, Anwar E, Hidayat T. 2017. Kandungan senyawa bioaktif bubur rumput laut Sargassum plagyophyllum dan Eucheuma cottonii sebagai bahan baku krim pencerah kulit. Jurnal Pengolahan Hasil Perikanan Indonesia. 20(3): 633-644.

Erawanti, T., Rosita, N., Hendroprasetyo, W., \&\& Juwita, D. R., 2005, Pengaruh jenis Basis Gel dan Penambahan $\mathrm{NaCl}(0,5 \%$-b/b) Terhadap Intensitas EchoGelombang Ultrasonik Sediaan Gel Untuk Pemeriksaan USG (Acoustic Coupling Agent), Airlangga Journal of Pharmacy, 5 (2) 
Guven, K.C., Percot, A., dan Sezik, E. 2010. Alkaloids in Marine Algae. Marine Drugs. 8(2): 269284.

Grace FX, Darsika C, Sowmya KV, Suganya K, Shanmuganathan S. 2015. Preparation and evaluation of herbal peel off face mask. American Journal of PharmTech Research. 5(4): 33-336.

Hidayat T, Nurjanah, Anwar E, Nurilmala M. 2017. Pengembangan teknologi tepat guna (TTG) rumput laut tropika sebagai bahan baku kosmetik. Creative Research Journal. 3(1): 37-42.

Herrero, M., Cifuentes, A., dan Ibanez, E. 2006. Sub-and Supercritical Fluid Extraction of Functional Ingredients from Different Natural Sources: Plants, Food-by-products, Algae and Microalgae: A review. Food chemistry. 98(1) 136-148.

Ji-Hyun O, Kim J, Lee Y. 2016. Antiinflammatory and Anti-diabetic Effects of Brown Seaweeds in High-fat Diet-induced Obese Mice. Nutrition Research and Practice. 10(1): 42-48.

Juliantina, F. R. 2008. Manfaat Sirih Merah (Piper crocatum) sebagai Agen Anti Bakterial terhadap Bakteri Gram Positif dan Gram Negatif. JKKI-Jurnal Kedokteran dan Kesehatan Indonesia.

Kessel RG. Basic Medical Histology. The biology of Cells, Tissues, and Organs. New York: Oxford University Press; 1998.

Khotimah, K., Darius, dan Sasmito, B.B. 2013. Uji Aktivitas Senyawa Aktif Alga Coklat (Sargassum fillipendulla) sebagai Antioksidan Pada Minyak Ikan Lemuru (Sardinella longiceps). THPI Student Journal Universitas Brawijaya. 1(1): 10-20

Kraan, S. 2013. Pigments and Minor Compounds in Algae. Functional Ingredients from Algae for Foods and Nutraceuticals.

Lachman, L, Lieberman, H, A, dan Joseph L, K, 1994 Teori dan Praktek Farmasi Industri, Edisi III, Penerbit Universitas Indonesia, UI - Press, Jakarta

Luthfiyana N, Nurjanah, Nurilmala N, Anwar E, Hidayat T. 2016. Rasio bubur rumput laut Eucheuma cottonii dan Sargassum sp. sebagai formula krim tabir surya. Jurnal Pengolahan Hasil Perikanan Indonesia. 19(3): 183-195.

Madduluri, S., Rao, K.B., Sitaram, B. 2013. In Vitro Evaluation of Antibacterial Activity of Five Indegenous Plants Extract Against Five Bacterial Pathogens of Human. International Journal of Pharmacy and Pharmaceutical Sciences. 5(4): 679-684.

Maharani F, Nurjanah, Suwandi R, Anwar E, Hidayat T. 2017. Kandungan senyawa bioaktif rumput laut Padina australis dan Eucheuma cottonii sebagai bahan baku krim tabir surya. Jurnal Pengolahan Hasil Perikanan Indonesia. 20(1):10-17.

Manivannan K, Thirumaran G, Karthikai DG, Anantharman P. 2008. Biochemical compositionof seaweed from Mandapam coastal region along southaest coast of India. American-Eurasian Journal of Botany. 1(2): 32-37. 
Martin, A., Swarbick, J., Cammara, A. and Chun, A. H. C. 1983, Farmasi Fisik, diterjemahkan dari Bahasa Inggris oleh Yoshita, UI Press, Jakarta.

Mishra, J.K., Srinivas, T., Madhusudan, T., dan Sawhney, S. 2016. Antibacterial Activity of Seaweed Halimeda opuntia from the Coasts of South Andaman. Global Journal of Bio-science and Biotechnology. 5(3): 345-348.

Mitzui, T. 1998. New ( Cosmetic Science. Amsterdam. Elsevier Science B. V. Hal 342 Moriss, k., 1993, Depilatories Mark Scubs and Bleaching Preparation, Paucher,S Perfumes Cosmetic and Soaps Hieda Butler, Chapman and Hall. London

Nurjanah, Nurilmala N, Anwar E, Luthfiyana N. 2017. Identification of bioactive compounds seaweed as raw sunscreen cream. Proceedings of the Pakistan Academy of Sciences: Pakistan Academy

Omar, H.H., Shiekh, H.M., Gumgumjee, N.M., El-Kazan, M.M., El-Gendy, A.M. 2012. Antibacterial Activity of Extracts of Marine Algae from the Red Sea of Jeddah, Saudi Arabia. African Journal of Biotechnology. 11(71): 1357613585

Pakidi, C.S., Hidayat, S.S. 2016. Potensi dan Pemanfaatan Bahan Aktif Alga Coklat Sargassum sp. Jurnal Ilmu Perikanan Octopus. 5(2).

Perez, M.J., Falqué, E., Domínguez, H. 2016. Antimicrobial Action of Compounds from Marine Seaweeda review. Marine Drugs. 14(52): 138

Rahmawanty D, Yulianti N, Fitriana M. 2015. Formulasi dan evaluasi masker wajah peel-off mengandung kuersetin dengan variasi konsentrasi gelatin dan gliserin. Media Farmasi. 12 (1): 17-32.

Rowe, R. C, Sheskey, P.J, Owen.S.C., 2006, Handbook of Pharmaceutical Excipients, 5 ed, Pharmaceutical Press,London, hal.81, 155,466,580-581,624-625,697,737,794.

Rowe, R. C, Sheskey, P.J., Quinn, M. E., 2009, , Handbook of Pharmaceutical Excipients. $6^{\text {th }}$ edition, Pharmaceutical Press and American Pharmacists Association, UAS, PP,110-113, 441445, 754-755.

Styawan,Ahmad dani. 2001. Petunjuk Praktikum Taksonomi 1. Solo:UNS Press

Syamsuni, 2006. Farmasetika Dasar dan Hitungan Farmasi.Penerbit Buku Kedokteran EGC. Jakarta.

Velasco, M. 2014. Short-term clinical of peeloff facial mask moisturizers. International Journal of Cosmetic Science. 36: 355-360.

Vieira RP, Fernandes AR, Kaneko TM, Consiglieri VO, Pinto CASO. 2009. Physical and physicochemical stability evaluation of cosmetic formulations containing soybean extract fermented by Bifidobacterium animalis. Brazilian Journal of Pharmaceutical Sciences. 45 (3):515-525. 
Venkateswarlu, S., Gopala K. P., Aditya L.G., Gottumukkala, V.S. 2007. Synthesis, Structural Revision, and Biological Activities of 4'Chloroaurone, A Metabolite of Marine Brown Alga Spatoglossum Variabile. Tetrahedron. 63 (29): 6909-6914

Vera, J., Castro, J., Gonzalez, A. And Moenne, A. 2011. Seaweed Polysaccharides and Derived Oligosaccharides Stimulate Defense Responses and Protection Against Pathogens in Plants. Marine drugs. 9(12): 2514-2525

Voight, R., 1994, Buku Pelajaran Teknologi Farmasi , diterjemahkan oleh Soewandhi, S. N., dan Widianto, M. B., Gadjah Mada University Press, Yogyakarta., pp. 141 - 145, 316 - 434.

Yanuarti R, Nurjanah, Anwar E, Hidayat T. 2017. Profil fenolik dan aktivitas antioksidan dari ekstrak rumput laut Turbinaria conoides dan Eucheuma cottonii. Jurnal Pengolahan Hasil Perikanan Indonesia. 20(2): 230-237.

Yeom G, Yun DM, Kang YW, Kwon JS, Kang IO, Kim SY. 2011. Clinical efficacy of facial masks containing yoghurt and Opuntia humifusa Raf. (F-YOP). J. cosmet Sci. 62(5): 505-514.

Young, Anne, 2002 v,Practical Cosmetic Science, 39-40, Mills and Boon Limited, London.

Wiguna, A.S., Lia, K., Ocky, K.R. 2016. Uji Aktivitas Antibakteri Pigmen Karotenoid dari Isolat Bakteri Simbion Karang Lunak Sarcophyton sp. terhadap Pertumbuhan Bakteri Staphylococcus aureus ATCC 25923. IJPST (Indonesian Journal of Pharmaceutical Science and Technology). 3(3): 92-98 